\title{
LAMB FATTENING OFF WHITE CLOVER IN POVERTY BAY
}

\author{
By D. P. SINCLAIR and J. E. V. SIMPSON
}

\section{Part I-Manutuke Research Station}

The Poverty Bay-east coast area is one of the major sources of store sheep in the North Island. Some $1,200,000$ breeding ewes are carried within the area and between 80 per cent. and 90 per cent. of lambs are tailed each year, which should give approximately 500,000 wether lambs available for disposal annually.

The areas of flat or easy land in the district are not extensive, but they are highly fertile and have a benign climate, and it might be expected that intensive store lamb fattening would be a feature of their farming. However, this is not the case. Feed crops are not widely grown., nor is pasture renewal with improved species practised as a routine of rotational cropping, and at present lamb fattening is largely dependent on the permanent pasture which is characteristic of the district, namely, a vigorous strain of perennial ryegrass of ancient origin and a primitive, low-producing strain of white clover which evidently fixes sufficient nitrogen for the ryegrass, but does not itself provide any significant amount of the total feed production. The result of using this pasture is that in recent years the only remaining freezing works of the district has killed less than 250,000 lambs at a low average carcass weight of between 30 and $311 \mathrm{~b}$.

In 1945 the Manutuke Research Station was established on the fertile flats near Gisborne for the primary purpose of investigating facial eczema, and since then an essential part of our work has been the study of weaned store lambs grazing on this typical permanent pasture during the late summer and autumn. The work has covered every stage of growth from summer drought through the most vigorous of autumn flush, but the outstanding feature has been that under no circumstances have the lambs done well on it.

The best weight gain recorded was this year, when lambs put on 15lb. liveweight in 11 weeks. Actual 
losses of body-weight for shorter periods during our facial eczema investigations are quite common, especially during the period of flush autumn growth, and on two occasions when stocked to its capacity at such time, typical hogget ill thrift has been produced.

From the foregoing observations it seems reasonable to assume that dependence on a permanent ryegrass dominant pasture is mainly responsible for the poor record of fat lamb production in Poverty Bay, and therefore, if full advantage is to be taken of this ready source of store lambs available for fattening without recourse to growing feed crops, some more suitable type of pasture must be established.

The question then arises: Which is the best type of pasture for fattening store lambs in Poverty Bay?

From the outset at Manutuke' a variety of improved and special-purpose pastures were established and used for fattening both during the spring with lambs on the mother and during the autumn with bought-in stores. Mr Simpson has reported the great increase in meat production obtained from all of these pastures when compared with the district average of lamb killings (1). In this earlier report, however, more emphasis was given to production of fat lambs off the mothers and here no one pasture mixture showed any clear-cut superiority, although short-rotation ryegrass and white clover appeared to be a little better than any other. In contrast, the results from autumn fattening were much more variable and differences occurred which were not explainable in terms of the original mixtures sown. During the course of this work it was observed that the improved strains of white cloves showed a marked tendency to dominate a sward during the late summer and autumn and therein lay the explanation of better lamb growth on some of the pas$\mathrm{t} \mathrm{u} \mathrm{r}$ e $\mathrm{s}$.

In 1949 it was recorded that this process of clover dominance was very marked in 3 of the 10 paddocks used. Table I shows the results from the autumn fattening trial that year, comparing clover-dominant pasture with non-clover-dominant.

It is not possible to present any accurate measurement of the percentage white clover content of these pastures, but when we use the term dominant we mean a sea of white clover and very little else.

Now the figures shown were more the result of fortunate circumstances than of planned experimenta- 
tion, but they strongly suggested that white clover was the ideal pasture plant for fat lamb production in Poverty Bay. In the 5 years since then, therefore, attention has been given to the production of fat lambs off almost pure stands of white clover. This work has been on a small scale and subsidiary to our main work

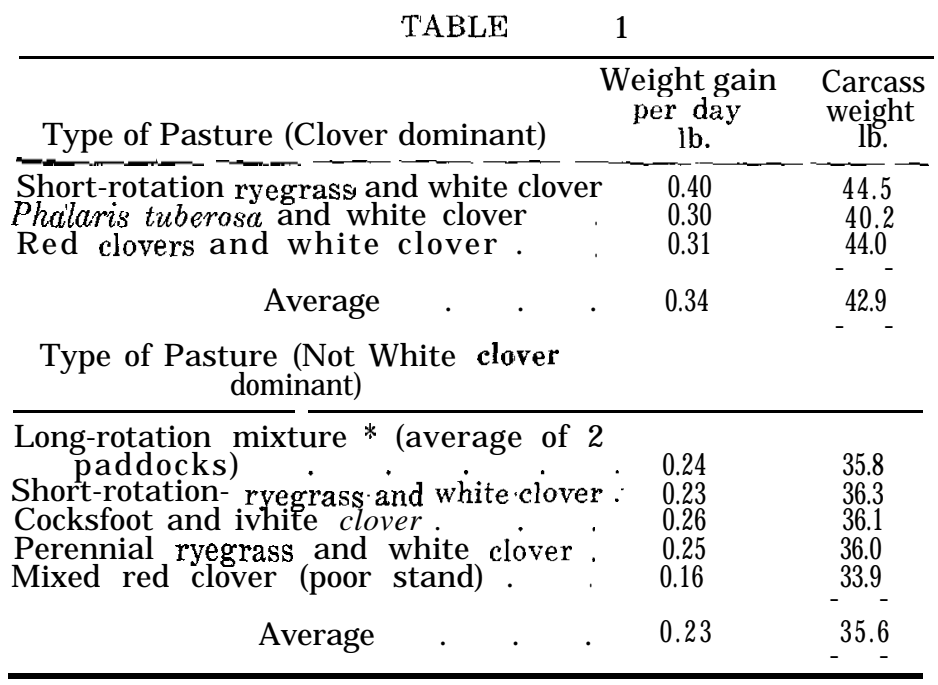

* Short-rotation ryegrass, timothy, cocksfoot, white clover, Montgomery, and broad red clover.

with facial 'eczema and maximum commercial returns have necessarily not been considered. In each case, however, medium store crossbred wether lambs with an average weight of between 55 and $621 \mathrm{~b}$. have been used. They were purchased from a typical hill country station in the latter part of January and were put on to the clover pastures soon after arrival at the station. They were weighed at the beginning and end of the feeding period and carcass weights were recorded at slaughter. They were set stocked and, with one exception and that for experimental reasons only, were not drenched nor supplemented in any way.

The results obtained are shown in Table 2 .

Where available, results from similar lambs grazing approximately during the same period on the old type of perennial ryegrass pasture are shown for comparison.

You will notice that each year from 1950 to 1952 the same lot of lambs were carried right through until May. This was necessitated by our work with facial 
eczema, which does not concern us here, but it is obvious from later results that such a practice is wasteful of good feed. As the lambs get heavier,. the growth rate slackens and, in practice, it would be more economical to kill the first lot of lambs after 10 weeks or so and restock with a further lot of stores.

TABLE 2

\begin{tabular}{|c|c|c|c|c|}
\hline 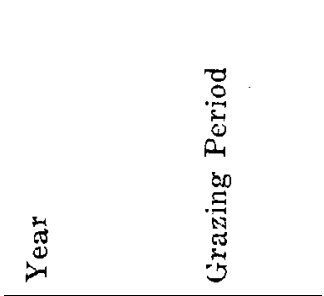 & 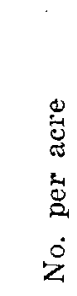 & 焉 & 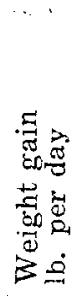 & 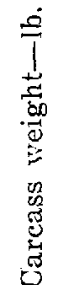 \\
\hline 195028 Jan.- 4 May & 10 & White clover & 9.33 & 42.5 \\
\hline 28 Jan.- 4 May & 10 & Old pasture & 0.12 & 31.3 \\
\hline 19516 Feb.- 8 May & 10 & White clover & 0.35 & 43.7 \\
\hline 6 Feb.- 8 May & 10 & Old pasture & 0.08 & 29.8 \\
\hline 195221 Jan.- 8 May & 10 & White clover & - & 43.0 \\
\hline 16 Jan.-28 May & 10 & Old pasture & 0.12 & 29.9 \\
\hline 195321 Jan.-17 Mar. & 10 & White clover & 0.56 & 38.0 \\
\hline \multicolumn{5}{|c|}{ No comparable figures available. } \\
\hline 195425 Jan.-12 Apl. & 10 & White clover & '0.44 & 43.3 \\
\hline 25 Jan. -12 Apl. & 10 & Old pasture & 0.19 & 33.2 \\
\hline 195420 Apl.-15 June & 8 & White clover & 0.29 & 37.8 \\
\hline 20 Apl.-15 June & 8 & Old pasture & 0.05 & 30.9 \\
\hline
\end{tabular}

However, apart from these financial aspects, it is obvious that white clover consistently produced excellent lambs and was very much superior to the old type of perennial ryegrass pasture for 5 years in succession, which covered an extreme range of very high and very low summer rainfall.

A further result in favour of white clover is that no evidence of facial eczema liver damage has been found in lambs grazing it, and, though no serious outbreak has occurred among lambs on perennial ryegrass, some liver damage has been found and there is always the risk that one day in the future another 1938 might occur.

In view of these results we consider that white clover is the best fattening feed for Poverty Bay, but it must be stressed that to obtain similar results, almost complete white clover dominance must be achieved in a pasture during the late summer and autumn, with the consequent risk that the ryegrass content may be smothered out entirely. The results you have seen were obtained from pastures in which this had happened, and before recommending them as 
a permanent proposition and describing their establishment and management, it is necessary to consider their production at other times of the year.

An experiment was conducted during the spring of 1950 in which fat lamb production on the mother from a 95 per cent. white clover pasture was compared with that from the old type of perennial pasture and from an improved pasture containing a well-balanced mixture of short-rotation ryegrass and white clover.

Four acres of each were set stocked with 10 ewes and 10 single lambs per acre from soon after. lambing in mid-August to weaning in early December. At weaning, a-draft of fats was taken and the remaining lambs were spread over the same areas until midJanuary, when a second pick was taken.

Production from each pasture is expressed as total 'percentage killed in the two drafts, together with average carcass weight.

TABLE 3

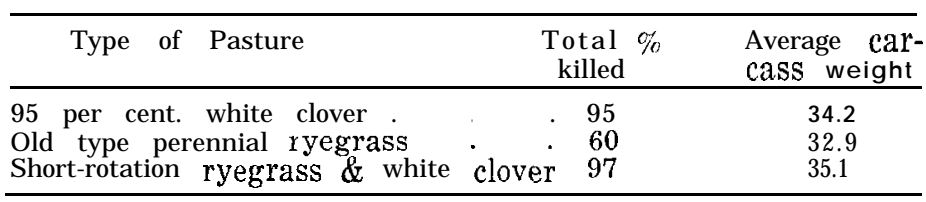

The good mixed pasture was only a little better than the pure white clover and both were definitely superior to the old type of perennial ryegrass. The lack of ryegrass was no definite disadvantage during the spring fattening period.

Now there remains only the winter grazing period to be considered. At Manutuke this lasts approximately from mid-June until mid-August. During this time the improved pastures are rationed to the ewe flock during the later stages of pregnancy for a few hours each day. The old perennial pastures are used as holding paddocks for feeding hay. For the last 2 years the white clover has provided the equivalent of 350 ewe grazing days per acre as compared with 700 from the good mixed pasture. To sum up, then, white clover alone is a pasture "par excellence" except for the relatively brief winter period.

Dry matter production measurements which were carried out on the three main types of pasture from 1 April 1949 to 31 March 1951 and grazing records which have been converted into arbitrary ewe equivalents show that the good mixed short-rotation rye- 
grass and white clover produced considerably more feed than white clover alone and, to a less extent, carried more stock.

TABLE 4

\begin{tabular}{|c|c|c|}
\hline Type of Pasture & $\begin{array}{c}\text { D.M. per acre } \\
\text { lb. }\end{array}$ & $\begin{array}{l}\text { Total Ewe } \\
\text { Equivalents }\end{array}$ \\
\hline $\begin{array}{l}\text { White clover } \\
\text { Short-rotation ryegrass } \\
\text { Old perennial ryegrass }\end{array}$ & $\begin{array}{r}9,600 \\
12,500 \\
10,500\end{array}$ & $\begin{array}{ll} & 2,350 \\
& 2,700 \\
\text { Not } & \text { significant }\end{array}$ \\
\hline
\end{tabular}

The big difference in dry matter production is not proportionately reflected in carrying capacity. Surplus growth of grass during the spring and autumn flushes is not fully utilised and, apart from a small number of cattle grazing days, the difference in carrying capacity is largely the result of growth of ryegrass during the winter. The ideal, therefore, is a pasture which is clover dominant during the summer and autumn and which will produce growth of ryegrass for winter feed. Like most similar propositions, it is extremely difficult to have it both ways, but to some extent it is possible, in Poverty Bay at least, by using a short-rotation ryegrass and white clover mixture.

In our normal dry summer, short-rotation ryegrass has more the characteristic of an annual than a perennial and tends to die out following seeding during the dry weather of December and January and, if encouraged, to come away again after the late autumn rain, In our experience if this mixture is leniently grazed at the onset of dry weather, the white clover will take over and persist throughout the summer and autumn and then, if it is grazed fairly hard during April to open it up, there will be regrowth of grass for winter feed. It does not always happen this way, as we have found.

The important thing to aim at is to establish a good sward of white clover for lamb fattening, and if the ryegrass is smothered out, it can readily be re-established by oversowing, which is neither costly nor difficult. Heavy grazing to open up the sward and broadcasting of $10 \mathrm{lb}$. of short-rotation ryegrass followed by chain harrowing have produced excellent winter pasture at Manutuke.

The usual methods of pasture establishment are well known and need no elaboration here, but the establishment and encouragement of white clover dom- 
inance in a mixed pasture requires 'some comment in relation to the Poverty Bay climate. To begin with there is some evidence that white clover establishes more quickly in a new pasture which is sown down after crops which have lowered the nitrogen content of the soil. For the last 2 years we have had more success with white clover in pastures which have followed a succession of brassica crops than in those which have been sown from grass to grass. Otherwise, the ratio of grass to clover appears to depend directly on the climate. In a wet summer which was experienced in 1952-53 when 10in. of rain fell in December and January, it was not possible to suppress the growth of ryegrass, but regular topping threw the balance in favour of the clover. In the dry summers which are typical of the East Coast in general the clover usually becomes dominant spontaneously, provided the pasture is leniently grazed or spelled before it gets too dry, which is usually in early December. Our experience has been that it is. essential to establish a cover of feed at least 6in. deep by this time. Evidently soil moisture is conserved and growth of clover continues throughout the average summer drought and usually provides fattening feed for at least 10 lambs per acre.

If, on the other hand, the pastures are eaten down at the onset of a dry period, no amount of spelling will bring the clover away until further rain falls and much of the summer's production is lost.

On the fat lamb property the surest method to guarantee a deep initial cover of feed is early weaning. As soon as dry weather sets in and the pastures show signs of being eaten down too short, weaning should take place, if necessary even before the end of November. The first pick of lambs can be taken and the remainder spread as lightly as possible. The ewes can be shut up on short rations until tupping.

By adopting this procedure at Manutuke during last season (1953-54) eight Down-cross lambs per acre were topped off from weaning until early January, and then from late January until June a total of 18 store lambs per acre were fattened in two drafts, the first during a period of summer drought when feed in the district was very short and the second after the autumn flush when hogget ill-thrift was prevalent. These lambs were not drenched or supplemented in any way and they returned a total stock profit of $£ 35$ per 
acre in five months, which, perhaps, is the most convincing argument of all that white clover is the feed for fattening lambs in Poverty Bay.

A criticism often levelled at this type of work is that it is done only on a small scale and might not work out under practical farming conditions. Mr Simpson, who three years ago went farming on his own behalf, has put a modified version of this scheme into practice and he will now conclude this talk by giving you the results he has obtained.

\section{REFERENCE.}

(1) J. E. V. Simpson, Procs. N.Z. Soc. An Prod. 1950.

Part II-Property of J. E. V. Simpson

The work at Manutuke has shown quite conclusively that a pasture containing a very high percentage of white clover fattens lambs well above the district average weight and well above the weight of lambs fattened on the old type Poverty. Bay perennial ryegrass and white clover pasture.

Three years ago I took over 150 acres of old type Poverty Bay perennial ryegrass and white clover pas.ture. Growth of the perennial ryegrass. in the winter was poor, in the spring was good, and in the summer the pasture became rusted and most unpalatable. In the autumn after the rains the herbage was poisonous with the facial eczema toxin, in fact, a most undesirable pasture species. The white clover did not grow in th,e winter, was suppressed by the perennial ryegrass in the spring, and in the late summer flowered profusely and contributed very little in the form of herbage. This pasture plant' was not pulling its weight.

During the first winter 200 ewes were grazed on 70 acres and hard pressed. The lambs born were small and the ewes did not milk well judging by the growth rate. On 10 December 45 per cent. of the lambs were picked averaging $32.5 \mathrm{lb}$.

This last season on 15 August. 140 ewes and 150 lambs were put on to a 12-acre paddock of Certified perennial rvegrass and white clover (80 per cent.). On 1 December 64 lambs averaging 36.6lb. were picked. The substantial difference in the carrying capacity and the amount of meat produced per acre is, I feel, a reflection on the difference in the clovers in the sward rather than the ryegrass. It is well known that 
the original Poverty Bay ryegrass was used in the first selection of ryegrass in producing our Certified perennial ryegrass now available.

I have pointed out the big difference in the weight of meat per acre and carrying capacity of the older type of pasture compared with the more recent selections of ryegrass and white clover. I realise that factual data such as carrying capacity and meat produced per acre are very difficult figures to obtain from a farmer with regard t'o any particular paddock on his farm. This autumn I have kept figures of lambs fat.tened on two fields on my farm; one a 14-acre paddock of Government stock short-rotation ryegrass (15 per cent.) and pedigree white clover (85 per cent.) and another paddock of 12 acres of Government stock perennial ryegrass (20 per cent.) and stock white clover (80 per cent.). These two fields were available for lamb fattening from early March, but were spelled until 19 March after the breaking of the drought earlier in the month.

The following table shows the date the lambs were purchased, number purchased, price paid, date lambs

TABLE 1

\begin{tabular}{|c|c|c|c|c|c|c|c|}
\hline Date of & & & & & & & \multirow{9}{*}{9} \\
\hline Purchase & No. & & st & & & & \\
\hline & & & d. & $\mathfrak{E}$ & s. & $\mathrm{d}$. & \\
\hline 19 March & 224 & 48 & 6 & 543 & 4 & 0 & \\
\hline 26 March & 131 & 40 & 0 & 262 & 0 & 0 & \\
\hline 30 April & 63 & 29 & 3 & 9 & 2 & 2 & \\
\hline 30 April & 250 & 38 & 0 & 475 & 0 & 0 & \\
\hline \multirow[t]{2}{*}{11 June } & 35 & 46 & 6 & 81 & 7 & 6 & \\
\hline & 703 & & & $£ 1453$ & 14 & 3 & \\
\hline Date of Pick & No. & Price & Received & & & & \multirow{12}{*}{$\begin{array}{c}\text { Dsd. Wt } \\
\text { lb. } \\
35.63 \\
36.18 \\
42.33 \\
31.98 \\
\text { Class } \\
\text { wethers. }\end{array}$} \\
\hline & & s. & d. & $\mathfrak{E}$ & s. & $\mathrm{d}$ & \\
\hline 22 April & 229 & 62 & 0 & 709 & 11 & 1 & \\
\hline 26 May & 120 & 65 & 0 & ,390 & 7 & 3 & \\
\hline 26 May & 3 & 77 & 6 & 11 & 12 & 7 & \\
\hline 26 Маy & 140 & 56 & 10 & 397 & 16 & 1 & \\
\hline 26 May & 6 & 48 & 6 & 14 & 11 & 1 & \\
\hline 28 June & 114 & 58 & 8 & 332 & 0 & 0 & \\
\hline \multirow[t]{2}{*}{28 June } & 37 & 53 & 8 & 99 & 4 & 10 & \\
\hline & 649 & & & $\$ 1955$ & 2 & 11 & \\
\hline \multirow[t]{2}{*}{ Value of 54} & lambs & unsold & $£ 2 / 5 /-$ & 121 & 10 & $\overline{0}$ & \\
\hline & & & & $£ 2076$ & 12 & & \\
\hline
\end{tabular}


picked, number picked, average price received, and dressed weight.

Actual cash return from 26 acres is $£ 501 / 8 / 8$, or about $£ 19 / 5 / 9$ per acre, and if the value of the 54 lambs unsold on June 28 is added, the return per acre is about $\$ 24$. When the total number of lambs purchased, 703, is divided into the cash return, $£ 501 / 8 / 8$, plus the value of the 54 lambs on hand, $\$ 121 / 10 /-$, the gross return per lamb is 17/8. After allowing for cartage from the saleyards to the farm and from the farm to the works plus the odd lamb which was drenched, a net profit of $16 / 6$ per lamb is shown.

I feel that the figures which I have given demonstrate that the application of research work to practical farming is possible and at the same time highly profitable.

DISCUSSION

What was the death rate in the lambs discussed?

A. (Sinclair) : None on white clover, but we were only dealing with 60 to 80 lambs a year.

(Simpson): Of 703 lambs I lost none, and this was on open grazing. There was a hold-up at the works and for a fortnight I had 416 lambs grazing, but even grazing at this rate they did not stop going ahead.

Q. What was the fertiliser programme ?

A. (Sinclair) : Zcwt. of superphosphate per acre, no lime, in May.

(Simpson) : I topdressed when I put the paddocks down and they have had nothing since.

Q. Had the lambs any access to roughage ? Could the speakers make any comparison with the results from red clover?

A. (Sinclair): They were set-stocked on small paddocks. We have had no success with red clover.

(Simpson): In the first year at Manutuke (1946) we had a paddock of red clover on which the lambs did fairly well. We 'let it get 15in. to 18in. high and the lambs did very well. We grazed it very hard next year. It was sown with Italian ryegrass. Next year we ploughed it in I didn't think we got a lot of grazing from red clover, but our management might have been wrong. It should have been used as a crop, not as a pasture. You can get quite a decent sward during winter with red clover when you don't get it with perennial.

Q. Was there any bloat?

A. (Sinclair) : No sign.

Q. What do you do when you get rid of the lambs?

A. (Sinclair) : We carried through lamb fattening to June and then as lambs were born we stocked up to elght ewes and lambs per acre. Late in January we were buying in stores again and so it goes on.

(Simpson): I actually sent lambs in to the works up to the end of July off some paddocks. I carried 10 hoggets per acre through the winter, sold them off, and hope to get a seed crop this year. 
Q. The lambs then were 12 months old. What grade were they

A. (Simpson): All prime. They were. born in September and were nine months old in June.

Q. Have you given any consideration to using white clover as a flushing feed for ewes?

A. (Sinclair) : We have done no experimental flushing at all. In Poverty Bay it is far more profitable to use the white clover for fattening than to seek any return from an increased lambing rate.

Q. Can the speakers comment on rape or York Globe turnips as fattening feed in comparison with white clover?

A. (Sinclair) : In later years when we have had more pure swards of white clover we have done no work on other crops.

Dr. Filmer: This example of a special practice for a special district could be recommended for any district on the east coast of the North Island where climatic conditions and the type of country are the same. At Ruakura it could not be, done and it should be tried with caution in other districts. 